The Journal of Developing Areas

Volume 49

No. 3

Summer 2015

\title{
PENSION ACCOUNTING DISCLOSURES AND STOCK MARKET REACTIONS
}

\author{
Nor Asma Lode and Mohd \\ Atef Md Yusof* \\ University Utara Malaysia, Malaysia
}

\begin{abstract}
The Malaysian Accounting Standard Board 'MASB' issued FRS 119 'Employee Benefits' which became effective for periods beginning on or after 1 January 2010. This standard is further superseded by MFRS 119 (i.e. as amended by IASB in June 2011) with effect from 1 January 2013. Hence, the present study provides evidence on the practice of pension accounting disclosures after the implementation of FRS 119 'Employee Benefits' and their stock market reactions 'cumulative market adjusted return'. The study reveals that seventy (70) companies have adopted Defined Benefit (DB) pension schemes based on the annual reports for the year 2009. Among these companies, seven (7) companies have pension assets disclosures while another 63 companies pension liabilities disclosures. The pension accounting disclosures related to actuarial gains and losses are only provided by 29 Malaysian companies. In addition, multivariate analysis provides interesting results that indicate pension liabilities disclosures are significant variables in relation to CMAR. These findings may suggest that $D B$ pension schemes with high disclosures of pension liabilities are less likely contributing to high value of CMAR. In this context, the users of corporate financial statements could be expected (1) to value the amount of pension liabilities more than amount of pension assets among DB pension schemes adopters; and (2) higher amount of pension liabilities may result in lower CMAR among DB pension schemes adopters in Malaysia. On the other hand, pension assets disclosures which are positively and significantly associated to CMAR indicate that the higher of pension assets disclosed in by $D B$ pension adopters in the financial statements, the higher of CMAR will be offered by Malaysian listed companies. These disclosures of pension asset could help the aging population in planning the retirement needs in the future. In addition, users of financial statements may be worth to be attentive and wacthful in relation to the amount of pension assets which are disclosed in the annual reports in order to make decision on buying and selling of company securities.
\end{abstract}

JEL Classifications: G1, G3, M4

Keywords: employee benefits, FRS 119, CMAR

Corresponding Author's Email Address: asma@uum.edu.my

\section{INTRODUCTION}

The implementation of Defined Benefit ' $D B$ ' pension schemes by Malaysian employers could be associated with the difficulties in measuring the retirement benefit. Pension benefit under DB pension plans is determined using an explicit formula which 
is commonly expressed as a percentage of salary at or near retirement and is usually dependent on services with the company (Dent \& Sloss, 1996). Determining the cost of providing these benefits under DB pension plans also involves many actuarial calculations which heavily depend on the assumptions (i.e. salary growth rates, employee turnover rates and mortality rates) used (Napier, 1983). In contrast, for Defined Contribution ' $D C$ ' pension plans, pension costs for a particular period are recognised in the income statement when the employer's contributions are due, according to the terms of the plan, in exchange for services rendered by employees during the period (IAS 19, para. 44). As a result, DB pension schemes are the focus in this study given the complexity in accounting for this type of plan.

The present study is the first study that provides evidence on the practice of pension accounting disclosures after the implementation of FRS 119 'Employee Benefits'. This study also contributes to the pension accounting literature in Malaysia context given that most literature has addressed issues of pension accounting on developed countries data. In particular, the objectives of this study are (1) to explore the extent of pension accounting disclosures after the implementation of FRS 119 among Malaysian listed companies; and (2) to examine the relationship of pension accounting disclosures and cumulative market adjusted return (CMAR).

\section{BACKGROUND AND HYPOTHESIS DEVELOPMENT}

IAS 19 'Employee Benefits' is adopted by Malaysian listed companies but this pension accounting standards which are issued by MASB is renamed as FRS 119 'Employee Benefits' in respect of its application in Malaysia. In 2003, MASB issued MASB 29 'Employee Benefits' to replace IAS 19 'Employee Benefits' (2000). This standard was named FRS 119 'Employee Benefits' in 2007. More recently, the MASB amends FRS 119 'Employee Benefits' which became effective for periods beginning on or after 1 January 2010. This standard is further superseded by MFRS 119 (i.e. as amended by IASB in June 2011) with effect from I Jan 2013.

Prior to the issuance of MFRS 119 (2003), studies have shown that there are diverse accounting practices for pension accounting among companies in Malaysia. Tan et al. (1998) examine pension accounting disclosures by the listed companies on KLSE (now Bursa Malaysia) for the year 1990. They found that most companies did not comply with the original IAS 19. In a similar vein, the disclosures of pension accounting for 99 companies in Malaysia for the year 2003 are still inadequate prior to FRS 119 (Shahrir et al., 2004). A study which investigates the extent of pension accounting disclosures before (i.e. for the year 2002) and after (i.e. for the year 2003) the effective date of FRS 119 based on 246 companies shows finds that the disclosures of pension accounting have slightly improved after the implementation date of the standard (Lode, 2006).

The current Malaysian accounting standard (FRS 119 'Employee Benefits') prescribes two distinct employee benefits plans specifically DB and DC. The employers should disclose the amount recognized as an expense for DC pension schemes (FRS 119, 2007). As for DB pension schemes which "provides benefits for employees on or after termination of service (either in the form of an annual income or as a lump sum) when such benefits, of the employer's contribution towards them, can be determined or estimated in advance of retirement from the provisions of a document or from the enterprise's practice" (FRS 129, Para 9), the disclosures are more complex. Therefore, the present study provides the evidence on the disclosures related to pension liabilities, pension assets, actuarial gains and losses and discount rates. 
In addition, previous researchers examine the association between the pension accounting information and share prices. For example, Feldstein and Seligman (1981), find that the share prices fully reflect the value of unfunded pension obligations. Landsman (1986) investigates whether pension fund assets and liabilities associated with corporate-sponsored DB pension plans. He provides evidence that pension fund assets and liabilities are valued by the market place no differently from other corporate assets and liabilities. Specifically, Amir and Ziv (1997) investigate the timing and method of adoption of SFAS No. 106 "Employers' Accounting for PostRetirement Benefits other than Pensions". They find that the market-adjusted return on a portfolio of 1991 adopters was significantly larger that the market-adjusted return on a portfolio of 1993 adopters.

Therefore, this study anticipates that the cumulative market adjusted return is related to companies that disclose pension accounting disclosures given that seventy companies have only adopted DB pension schemes in Malaysia. Therefore, the hypothesis is stated as follows:

H1: The cumulative market adjusted return (CMAR) is related to pension accounting disclosures among Malaysian listed companies.

\section{RESEARCH METHOD}

Annual reports from all listed companies (banks and financial institutions will be excluded because they are subject to a different legal requirement) on the Main Board for the year 2009 are collected either through library search. Pension related-assets and liabilities disclosures, Disclosures associated to actuarial gains and losses, discount rate, salary progressive rate disclosed in the annual report are manually collected from the annual reports. Apart from annual reports of companies' websites, data such as EPS and stock returns (i.e. CMAR) are collected from data stream.

Brown (1985) has initiated normal returns as either an arithmetic average of historical return or required return from the Capital Asset Pricing Model. The latter method is called cumulative market-adjusted return (CMAR) which is also known as cumulative abnormal return (CAR). The present study determines CMAR which is replicated based on study by Amir and Ziv (1997). 60 days of cumulative marketadjusted return (CMAR) prior to the date of adoption and ending 60 trading days after this date for each firm is computed. The financial year end date of the annual report is to be used as adoption date in the present study.

The CMAR is calculated as follows:

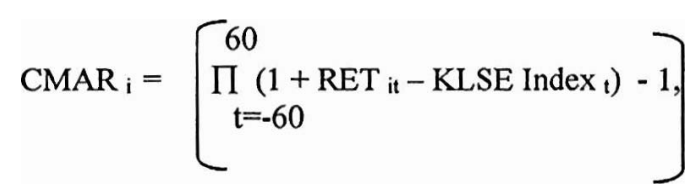

$\mathrm{RET}_{\text {it }}=$ firm i's daily return at time t; Kuala Lumpur Stock Exchange 'KLSE' Index $t=$ the daily return on the KLSE index at time $t$ and day 0 is day of adoption. 


\section{FINDINGS}

\section{Descriptive Analysis}

Descriptive analysis related to CMAR and pension accounting disclosures (i.e. pension acconting disclosures, pension liabilities disclosures, actuarial gains and losses and discount and salary progressive rate) are presented in Table 1.

\section{Pension asset disclosures}

Pension assets are pension promises to be financed in advance by setting aside of specific assets, whether this comes about through the employer merely designating particular assets over which it retains ownership or whether the employer transfers resources to a third party, such as a trust (Napier, 2009). FRS 119 requires assets in a DB scheme to be measured at the fair value at the balance sheet dates (FRS 17, para. 14). The question arises as to whether the employer should show a gross liability, with any pension assets disclosed separately, or net liability, deducting any pension assets from pension liability.

Referring to disclosures and descriptive analysis based on Malaysian listed companies, there are only seven (7) companies (Commerce International Merchant Bankers, Media Chinese International, Nestle, Proton, Bandar Raya Development, MBM Resources, Eng Teknologi Holdings) that disclosed pension assets ranging RM152,000 to RM358 million while another 63 companies disclosed pension pension liabilities only. These findings indicate that majority of DB pension schemes in Malaysia are unfunded since the pension liabilities are not reflected by pension liabilities in the financial statements. In other words, the employers could simply settle the pension obligations as they fall due out of current resources.

\section{TABLE 1. DESCRIPTIVE STATISTICS: PENSION ACCOUNTING DISCLOSURES AND CMAR}

\begin{tabular}{lrrrr} 
& \multicolumn{1}{c}{ Minimum } & \multicolumn{1}{l}{ Maximum } & \multicolumn{1}{l}{ Mean } & \multicolumn{1}{l}{ Std. Deviation } \\
Pension assets & 0.00 & 19.70 & 1.39 & 4.35 \\
(Ln) & & & & \\
Pension liabilities & 3.64 & 19.83 & 11.87 & 4.20 \\
(Ln) & & & & \\
AGL (Ln) & 0.00 & 15.82 & 2.60 & 4.92 \\
Total Asset (Ln) & 10.63 & 26.70 & 17.42 & 4.13 \\
CMAR & 0.25 & 2.09 & 1.01 & 0.29
\end{tabular}

\section{Pension liability disclosures}

The employers' pension fund commitments arising from employees' service are first measured as a pension liability as the present value of future benefits 'PVFB' (Napier, 1983). This PVFB represents the discounted value of the payments which the employers have promised to the employees in respect of all services, past and future. The disclosure requirements related to pension liabilities became mandatory to provide financial statement users with adequate disclosure of the cost of providing retirement benefits and the related gains, losses, assets and liabilities (FRS 119, 2007). DB scheme 
liabilities should be measured on an actuarial basis using the projected unit method, whereby the liabilities comprise (1) any benefits promised under the formal terms of the scheme, and (2) any constructive obligations for further benefits where a public statement or past practice by the employer has created a valid expectation in the employees that such benefit will be granted (FRS 119, 2007).

Malaysian listed companies (i.e. seventy companies) that adopted DB pension schemes are fully complied with FRS 119 by disclosing the amount of pension liabilities. The highest is RM410 million by Commerce International Merchant Bankers while the lowest is RM38 by Integrated Software Solution. The average of pension liabilities disclosed among Malaysian listed companies is RM210 million. The analysis of disclosures also suggest that DB pension schemes are mostly categorised as unfunded ${ }^{6}$ pension schemes given that the same companies did not have pension assets disclosures. Therefore, do these disclosures potentially enhance the transparency of a company's economic obligations and improve analysts' ability in predicting future earnings and cash flows?

\section{Actuarial Gains and Losses disclosures}

AGL had been disclosed in the financial statements by 29 companies (i.e. $41 \%$ ). The reported $A G L$ is equally disclosed between gains and losses, whereby $52 \%$ of companies reported actuarial losses and $48 \%$ of companies reported actuarial gains. The highest actuarial losses of RM18 million by Commerce International Merchant Bankers, while the highest actuarial gains of RM7.4 million were reported by Tenaga Nasional. The remaining companies (i.e. $59 \%$ ) that did not disclose pension liabilities were not mentioning their AGL in the financial statements.

\section{Discount Rate and Salary Progressive Rate Disclosures}

DB schemes should be discounted at a rate that reflects the time value of money on a high quality corporate bond (FRS 17, para. 32) and full actuarial valuations by a professionally qualified actuary should be obtained for a DB scheme at intervals not exceeding 3 years (FRS 17, para. 35). The average of discount rate that had been used by majority of DB pension schemes adopters in Malaysia was $6.44 \%$. Nevertheless, a few companies such as Delloyd, Scomi Marine and Pharma Niaga discounted their DB pension schemes at $11 \%$.

In addition, the average of salary progressive rate (SPR) that was disclosed by employers in Malaysia was $5.55 \%$. The highest of SPR which was disclosed by Integrated Software Solution and Southern Acids (M) was 10\%. On the other hand, CNI and Central Industrial Corporation reported the lowest of SPR at 3\%. More interestingly, some companies disclosed their SPR in a range format, for example between $3 \%$ and $9 \% ; 4 \%$ and $12 \%$. These reported rates were less likely helping the analysts and the users of financial statement in predicting future growth of the companies.

\section{Cumulative market adjusted return (CMAR)}

Table 1 provides evidence that the average of CMAR among DB pension scheme adopters was 1.01. In addition, the maximum of CMAR disclosed by employers in Malaysia was 2.09 , while the minimum was 0.25. Eng Teknologi Holdings Berhad reported the highest CMAR, whereas LCL Corporation Berhad reported the lowest CMAR among DB pension schemes adopters. Descriptive analysis also shows that 
CMAR is positive among 70 companies that implement DB pension schemes. These findings seem to offer interesting results in a relationship between CMAR and pension accounting disclosures (i.e. pension assets, pension liabilities and actuarial gains and losses).

\section{Correlation Analysis}

Table 2 illustrates the correlation analyses for dependent variables and continuous independent variables that include pension assets, pension liabilities, actuarial gains and losses (AGL), earnings per share (EPS) and total assets. A high correlation between (1) CMAR and EPS; (2) AGL and pension assets; and (3) pension liabilities and total assets has been shown in the correlation analysis. These findings indicate that EPS could be a significant variable to explain CMAR among DB pension adopters among Malaysian listed companies.

\section{TABLE 2: PEARSON CORRELATION ANALYSIS}

\begin{tabular}{|c|c|c|c|c|c|c|}
\hline & CMAR & $\begin{array}{l}\text { Pension } \\
\text { assets } \\
\text { (Ln) }\end{array}$ & $\begin{array}{l}\text { Pension } \\
\text { liabilities } \\
\text { (Ln) }\end{array}$ & $\begin{array}{c}\text { EPS } \\
\text { (cents) }\end{array}$ & $\begin{array}{l}\text { AGL } \\
\text { (Ln) }\end{array}$ & $\begin{array}{l}\text { Total } \\
\text { Asset } \\
\text { (Ln) }\end{array}$ \\
\hline CMAR & 1.000 & & & & & \\
\hline $\begin{array}{l}\text { Pension assets } \\
\text { (Ln) }\end{array}$ & 0.249 & 1.000 & & & & \\
\hline $\begin{array}{l}\text { Pension } \\
\text { liabilities (Ln) }\end{array}$ & -0.045 & 0.262 & 1.000 & & & \\
\hline EPS (cents) & $0.325 * *$ & 0.178 & 0.033 & 1.000 & & \\
\hline AGL (Ln) & -0.085 & $\overline{0.505^{* *}}$ & -0.123 & -0.124 & 1.000 & \\
\hline Total Assets (Ln) & 0.045 & 0.316 & $0.831 * *$ & 0.007 & -0.093 & 1.000 \\
\hline
\end{tabular}

*. Correlation is significant at the 0.05 level.

**. Correlation is significant at the 0.01 level

\section{Multivariate Analysis}

Multiple regression models (i.e. Model 1 and Model 2) are developed to investigate the relationship between pension accounting disclosures and CMAR. The regression analysis provides evidence that pension assets disclosures are significantly and positively related to CMAR among Malaysian listed companies. This positive coefficient of pension assets implies that pension assets disclosed by DB pension adopters in the financial statements are more likely to provide higher CMAR. These disclosures of pension asset ranging RM152,000 to RM358 million seem to help the aging population in planning the retirement needs in the future. In addition, users of financial statements may be worth to be attentive and wacthful in relation to the amount of pension assets which are disclosed in the annual reports in order to make decision on buying and selling of company securities.

Furthermore, Model 2 in Table 3 provides evidence that pension liabilities disclosures are negatively related to CMAR at $10 \%$ significant level. These significant 
findings indicate that the disclosures of pension related liabilities are more likely to provide lower CMAR among DB pension schemes adopters in Malaysia. In other words, companies that disclosed higher pension liabilities in the annual reports would be expected to have lower CMAR on average than companies with lower amount of pension liabilities. In a similar vein, Chuk (2013) suggests that the economic consequences of FASB standards can contribute to increased association of stock price and aggregate pension underfunding (i.e., when pension obligations exceed pension assets).

Other pension accounting disclosures (i.e. actuarial gains and losses) are not significantly related to CMAR as evidenced in Model 1 and 2. These insignificant findings are likely to be associated to the amount of actuarial gains and losses which are not separately examined in the present study. More interestingly, EPS which is used as an additional variable in the present study reveals a significant relationship between CMAR and EPS in Model 1 and 2 at the expected direction of coefficient. The consistent result of significant and positive coefficient of EPS in both models indicate that market reacts and responses to the announcement of earnings. Table 3 further shows that the adjusted $R^{2}$ is $8.8 \%$ and $7.7 \%$ for Model 1 and 2 respectively. In addition, Durbin-Watson values which are 1.58 and 1.48 indicate that there are no autocorrelation amongst variables.

TABLE 3: REGRESSION OF CMAR AND CONTINUOUS INDEPENDENT VARIABLES Pension Assets $+\varepsilon_{\mathrm{it}}$

(1) $\mathrm{CMAR}=a+\beta_{1} \mathrm{EPS}+\beta_{2}$ Total Assets $+\beta_{3} \mathrm{AGL}+\beta_{4}$ (2) $\mathrm{CMAR}=a+\beta_{1} \mathrm{EPS}+\beta_{2}$ Total Assets $+\beta_{3} \mathrm{AGL}+\beta_{4}$ Pension Liabilities $+\varepsilon_{\text {it }}$

\section{Model 2}

$$
\text { Expected sign Model } 1
$$

$\begin{array}{lrrr}\text { Intercept } & & 0.99 & 0.87 \\ & & (\mathbf{6 . 2 5})^{* *} & (\mathbf{5 . 4 2})^{* *} \\ \text { EPS } & + & 0.29 & 0.33 \\ & & (\mathbf{2 . 3 4})^{* *} & (\mathbf{2 . 6 3})^{* *} \\ \text { Total Assets } & + & -0.03 & 0.29 \\ & & (-0.21) & (1.31) \\ \text { AGL } & - & 0.07 & -0.05 \\ & & (0.49) & (-0.44) \\ \text { Pension Assets } & + & 0.24 & \\ & & (1.61)^{*} & \\ \text { Pension Liabilities } & - & & -0.30 \\ & & & (-1.40)^{*} \\ \text { Adjusted R } & & & 7.7 \%\end{array}$


* Significant at the $10 \%$ level.

**Ssignificant at the $5 \%$ level.

\section{CONCLUSIONS}

The present study provides evidence on the pension accounting disclosures among listed companies after the implementation of FRS 119 'Employee Benefits' among Malaysian listed companies. The study reveals that seventy (70) companies have adopted Defined Benefit (DB) pension schemes based on the annual reports for the year 2009. Among these companies, seven (7) companies have pension assets disclosures while another 63 companies pension liabilities disclosures. The pension accounting disclosures related to actuarial gains and losses are only provided by 29 Malaysian companies.

In addition, multivariate analysis provides interesting results that indicate pension liabilities disclosures are significant variables in relation to CMAR. These findings may suggest that DB pension schemes with high disclosures of pension liabilities are less likely contributing to high value of CMAR. In this context, the users of corporate financial statements could be expected (1) to value the amount of pension liabilities more than amount of pension assets among DB pension schemes adopters; and (2) higher amount of pension liabilities may result in lower CMAR among DB pension schemes adopters in Malaysia.

On the other hand, pension assets disclosures which are positively and significantly associated to CMAR indicate that the higher of pension assets disclosed in by DB pension adopters in the financial statements, the higher of CMAR will be offered by Malaysian listed companies. These disclosures of pension asset could help the aging population in planning the retirement needs in the future. In addition, users of financial statements may be worth to be attentive and wacthful in relation to the amount of pension assets which are disclosed in the annual reports in order to make decision on buying and selling of company securities.

In summary, these findings raise issues on (1) how much accountants and preparers of financial statements in Malaysia understand the requirement of FRS 119; and (2) do regulators and policy makers of pension accounting standards in Malaysia aware the disclosures by DB pension schemes adopters are important to users of financial statements (e.g. the aging population) in predicting their retirement financial needs. In addition, these disclosures could potentially enhance the transparency of a company's economic obligations and improve analysts' ability in predicting future earnings and cash flows.

Finally, the present study on pension accounting disclosures and CMAR in Malaysia context sheds light on the issues surrounding pension accounting to researchers, accounting standard setters, financial reporting regulators, users and preparers of corporate financial reports. However, the limitation in methodology may restrict generalisability of the findings due to the small sample of 70 companies of DB pension schemes adopters in Malaysia. Future research could be extended to other sample companies in other developing and developed countries. 


\section{ENDNOTES}

*Acknowledgement

I would to thank to Ministry of High Education (MOHE) for the grant provided, and participants at Australian Academy of Business and Social Sciences (AABSS) conference 2014 for their suggestions throughout writing this paper. I am also thankful to the anonymous referee for the useful comments. The remaining errors are my own.

\section{REFERENCES}

Amir, E. and Ziv, A., "Recognition, disclosure, or delay: timing the adoption of SFAS No.106", 1997, Journal of Accounting Research, Vol. 35, pp. 61-81.

Dent, K. and Sloss, D., "The global outlook for defined contribution versus defined benefit plans", 1996, Benefit Quarterly, First Quarter, pp. 23-28.

Feldstein, M. and Seligman, S., "Pension Funding, Share Prices and National Savings", 1981, The Journal of Finance, September, pp. 801-824.

Landsman, W., "An empirical investigation of pension fund property rights". 1986, The Accounting Review, Vol. LXI, No. 4, pp. 661-691.

Lode, N. A., "Retirement benefit plans among Malaysian listed companies", 2006, Unpublished Manuscript, Universiti Utara Malaysia.

Malaysian Accounting Standard Board, Financial reporting standard 119, Employee benefits, 2003, MASB.

Malaysian Accounting Standard Board, Financial reporting standard 119, Employee benefits, 2007, MASB.

Napier, C. J., "Accounting for the cost of pensions", 1983, The Institute of Chartered Accountants in England and Wales, London

Shahrir, M. R., Atef, M. M. Y., and Sharofi, M. I., "The Reporting of Retirement Benefits Prior to MASB 29", 2004, Proceedings of International Conference of Corporate Governance and Reporting, pp. 406-419.

Tan, L. T., Veerinderjeet, S., Barjoyai, B., Loo, S. C., Unvar, R. M., and Mahfudzah, M., "Financial Reporting - A Survey of Malaysian Financial Reporting Practices", 1998, Educational Trust Fund Research Monograph, pp. 18-143. 